\title{
ANALISIS KESALAHAN BERBAHASA INDONESIA PADA TEKS ILMIAH MAHASISWA
}

\author{
${ }^{1)}$ Bayu Dwi Nurwicaksono, ${ }^{2)}$ Diah Amelia \\ ${ }^{1)}$ 2) Politeknik Negeri Media Kreatif \\ E-mail: bayudn@polimedia.ac.id
}

\begin{abstract}
ABSTRAK
Tujuan penelitian ini untuk mendeskripsikan bentuk kesalahan berbahasa tulis yang sering dilakukan mahasiswa. Metode penelitian yang digunakan ialah metode deskriptif analisis. Data penelitian ialah teks ragam ilmiah yang dibuat mahasiswa berupa ulasan terhadap buku yang dibacanya. Hasil penelitian menunjukkan adanya kesalahan berbahasa kategori error $89,08 \%$, bentuk mistake 10,71\%, dan bentuk lapses $0,2 \%$. Temuan error pada kesalahan pemakaian huruf mencapai 183 item atau 43,16\%, temuan error pada kesalahan penulisan kata mencapai 145 item atau 34,20\%, temuan error pada pemakaian tanda baca mencapai 68 item atau 16,04\%, temuan error pada penulisan unsur serapan mencapai 28 item atau 6,6\%. Temuan-temuan tersebut membuktikan bahwa kompetensi mahasiswa Program Studi Penerbitan dalam penguasaan Ejaan Bahasa Indonesia sangat perlu ditingkatkan. Hasil analisis kesalahan berbahasa dalam penelitian ini dapat dijadikan bahan ajar untuk pembelajaran bahasa Indonesia khususnya materi ejaan.
\end{abstract}

Kata kunci: kesalahan berbahasa Indonesia, teks ilmiah, mahasiswa

\section{ANALYSIS OF INDONESIAN LANGUAGE ERRORS ON STUDENTS OF SCIENTIFIC TEXT}

\begin{abstract}
The purpose of this study is to describe the form of written language errors that is often done by students. The research method used is descriptive analysis method. The research data is a scientific variety text made by students in the form of a review of the books they read. The results showed an error in the error category of $89.08 \%$, a mistake in the form of $10.71 \%$, and a form of lapses of $0.2 \%$. The finding of errors in letter usage errors reached 183 items or $43.16 \%$, the finding of errors in word writing errors reached 145 items or $34.20 \%$, the findings of errors in the use of punctuation reached 68 items or $16.04 \%$, error findings in writing elements uptake reached 28 items or $6.6 \%$. These findings prove that the student competency of the Publishing Study Program in
\end{abstract}


mastering Indonesian Spelling really needs to be improved. The results of language error analysis in this study can be used as teaching materials for learning Indonesian especially spelling material.

Keywords: Indonesian language errors, scientific texts, students

\section{PENDAHULUAN}

Kebijakan sertifikasi profesi di bidang editor buku akan mulai diberlakukan pada tahun 2019. Pada tahun 2018 ini telah terbit Surat Keputusan Menteri Ketenagakerjaan Republik Indonesia Nomor 124 Tahun 2018 tentang Penetapan Standar Kompetensi Kerja Nasional Indonesia (SKKNI) Kategori Informasi dan Komunikasi Golongan Pokok Aktivitas Penerbitan Bidang Penerbitan Buku. Salah satu unit kompetensi yang terkait dengan bidang editor ialah menyelia penyuntingan naskah. Unit kompetensi ini berhubungan dengan pengetahuan, keterampilan, dan sikap kerja yang dibutuhkan dalam menyelia proses penyuntingan naskah. Salah satu elemen kompetensi tersebut ialah menyelia penyuntingan mekanis yang kriteria unjuk kerjanya berupa naskah suntingan diperiksa sesuai dengan aspek keterbacaan, ketaatasasan, dan kebahasaan.

Mahasiswa Program Studi Penerbitan ialah calon lulusan yang akan mengisi ruang-ruang editorial di perusahaan penerbitan atau media massa. Sebagai calon editor muda, mereka harus memiliki kompetensi menyelia penyuntingan naskah secara mekanis. Untuk menggambarkan kondisi riil kemampuan awal mahasiswa dalam bidang editing, perlu dilakukan penelitian deskriptif analisis kesalahan berbahasa tulis mahasiswa dalam teks ulasan buku.

AKSIS Jurnal Pendidikan Bahasa dan Sastra Indonesia 
Corder dalam Fisiak (1981) menyatakan bahwa kesalahan berbahasa terdiri atas tiga istilah, yakni (1) lapses, (2) error, (3) mistake. Lapses adalah kesalahan berbahasa akibat penutur beralih cara untuk menyatakan sesuatu sebelum tuturan (kalimat) selesai dinyatakan secara lengkap. Kesalahan ini terjadi akibat ketidaksengajaan dan tidak disadari oleh penuturnya. Error adalah kesalahan berbahasa akibat penutur melanggar kaidah atau aturan tata bahasa (breach of code). Kesalahan ini terjadi akibat penutur sudah memiliki aturan atau kaidah tata bahasa yang berbeda dari tata bahasa yang lain sehingga berdampak pada ketidaksempurnaan tuturan. Mistake adalah kesalahan berbahasa akibat penutur tidak tepat dalam memilih kata atau ungkapan untuk situasi tertentu. Kesalahan ini mengacu kepada kesalahan akibat penutur tidak tepat menggunakan kaidah yang diketahui benar, bukan karena kurangnya penguasaan bahasa kedua (B2).

Sementara itu, Tarigan (1990) menyatakan bahwa istilah error dan mistake saling bersinonim atau memiliki makna kurang lebih sama. Error berarti kesalahan sedangkan mistake berarti kekeliruan. Kesalahan berbahasa mengacu pada penggunaan bahasa yang menyimpang dari kaidah bahasa yang berlaku dalam bahasa itu. Sementara itu, kekeliruan adalah penggunaan bahasa yang menyimpang dari kaidah bahasa yang berlaku dalam bahasa itu, tetapi tidak dipandang sebagai suatu pelanggaran berbahasa, misalnya kekeliruan yang terjadi pada anak (siswa) yang sedang belajar bahasa. Kekeliruan cenderung diabaikan dalam analisis kesalahan berbahasa karena sifatnya tidak acak, individual, tidak sistematis, dan tidak permanen (bersifat sementara).

Dalam bukunya, Norish (1983) menyatakan bahwa error adalah kesalahan yang dibuat secara terus menerus oleh siswa dan mereka tidak dapat memperbaiki error 
tersebut jika mereka tidak mendapat penjelasan dari guru. Senada dengan pernyataan tersebut, Brown (2000) menyatakan bahwa error adalah kesalahan umum yang dibuat mahasiswa dan menunjukkan seberapa baik kemampuan mereka dalam menulis.

Berdasarkan ulasan tersebut, dapat disimpulkan bahwa kesalahan berbahasa adalah penggunaan bahasa yang menyimpang dari kaidah bahasa yang berlaku dalam suatu bahasa. Oleh karena itu, analisis kesalahan berbahasa dalam konteks penelitian ini adalah penggunaan bahasa Indonesia secara tulis yang berada di luar kaidah kebahasaan atau menyimpang dari faktor-faktor komunikasi.

Dulay, Burt, dan Krashen (1982) membedakan wilayah taksonomi kesalahan berbahasa menjadi empat, yakni (1) taksonomi kategori linguistik, (2) taksonomi kategori strategi performansi, (3) taksonomi kategori komparatif, dan (4) taksonomi kategori efek komunikasi. Dalam konteks penelitian ini, wilayah taksonomi yang dijadikan titik pijak adalah taksonomi kategori linguistik, yakni kesalahan tataran fonologi, kesalahan tataran morfologi dan sintaksis, kesalahan tataran semantik dan kata, serta kesalahan tataran wacana.

Kesalahan berbahasa pada tataran fonologi meliputi perubahan pengucapan fonem, penghilangan fonem, dan perubahan bunyi diftong menjadi bunyi tunggal atau fonem tunggal. Analisis kesalahan berbahasa pada tataran morfologi terbagi atas kesalahan afiksasi, kesalahan reduplikasi, dan kesalahan pemajemukan (Utami, 2017). Kesalahan berbahasa pada tataran sintaksis berupa kalimat tidak bersubjek dan tidak berpredikat, kalimat tidak berpredikat, penggandaan subjek, antara predikat dan objek yang tersisipi, kalimat yang tidak logis, kalimat yang ambigu, penghilangan konjungsi, 
penggunaan konjungsi yang berlebihan, urutan yang tidak paralel, penggunaan istilah asing, dan penggunaan kata tanya yang tidak perlu. Kesalahan berbahasa pada tataran semantik meliputi kesalahan penggunaan kata-kata yang mirip dan pilihan kata yang tidak tepat (Kurniadi, 2017). Kesalahan pada tataran wacana meliputi faktor kohesi dan faktor koherensi.

Dalam konteks penelitian ini, yang menjadi alat analisis kesalahan berbahasa ialah tataran morfologi. Tataran fonologi, sintaksis, tataran semantik, dan tataran wacana tidak menjadi alat analisis dalam penelitian ini karena data berupa morfem bahasa Indonesia ragam tulis yang terdapat pada ulasan buku atau resensi buatan mahasiswa.

Kosasih (2014) menyatakan bahwa aspek yang harus diperhatikan dalam penyuntingan teks ulasan adalah ketepatan penulisan ejaan dan tanda baca. Teks ulasan berbentuk tertulis dalam bentuk makalah atau laporan, artikel ataupun esai. Bahasa yang digunakan cenderung baku. Teks ulasan pada umumnya diawali dengan penyampaian isu yang berupa identitas dan sinopsis karya yang akan diulas. Struktur teks ulasan mencakup (1) pendahuluan sebagai pengenalan isu yang berisi identitas buku dan sinopsisnya; (2) analisis berupa argumen-argumen sebagai pembahasan atas kelebihan dan kekurangan dari unsur-unsur yang terkait tujuan dan manfaat penulisan, latar belakang penulis, bahasa yang digunakan, garis besar isi buku, kualitas substansi isi, kover, dan cetakan; (3) penutup berisi simpulan kelebihan dan kekurangan serta saran atau rekomendasi buku untuk khalayak. Selain itu, perlu diperhatikan pula penggunaan kaidah-kaidah kebahasaan yang lazim digunakan dalam teks ulasan, yakni ketepatan penggunaan kata sifat, kata-kata bermakna perincian, dan kata-kata teknis bidang 
perbukuan. Ketepatan yang dimaksud berkenaan dengan makna, konteks penggunaan, dan ejaannya.

\section{METODE}

Metode penelitian yang digunakan dalam penelitian ini adalah metode deskriptif analisis. Menurut Suriasumantri (2005), metode deskriptif analisis ialah metode yang digunakan untuk meneliti gagasan atau produk pemikiran manusia yang telah tertuang dalam bentuk media cetak, baik yang berbentuk naskah primer maupun naskah sekunder dengan melakukan studi kritis terhadapnya. Fokus penelitian deskriptif analisis adalah berusaha mendeskripsikan, membahas, dan mengkritik gagasan primer yang selanjutnya dikonfrontasikan dengan gagasan primer yang lain dalam upaya melakukan studi berupa perbandingan, hubungan, dan pengembangan model. Pelaksanaan metode penelitian deskriptif tidak terbatas pada pengumpulan dan penyusunan data, tetapi juga analisis dan interpretasi tentang data tersebut.

Dalam konteks penelitian ini, metode deskriptif analisis digunakan sebagai metode awal yang digunakan untuk menjelaskan fenomena yang ada sesuai dengan kondisi riil di lapangan. Tarigan (1990) memodifikasi langkah-langkah menganalisis kesalahan berbahasa yang diajukan Ellis dan Sidhar dengan urutan sebagai berikut (1) mengumpulkan data yang berupa kesalahan-kesalahan berbahasa yang dibuat pembelajar, (2) mengidentifikasi dan mengklasifikasi kesalahan dengan tahap pengenakan dan pemilahan kesalahan berdasarkan kategori ketatabahasaan, (3) membuat peringkat kesalahan yang berarti membuat urutan kesalahan berdasarkan keseringan kesalahan-kesalahan itu muncul, (4) menjelaskan kesalahan dengan mendeskripsikan letak kesalahan, sebab-sebabnya dan pemberian contoh yang benar, 
(5) membuat perkiraan daerah atau butir kebahasaan yang rawan menyebabkan kesalahan, (6) mengoreksi kesalahan berupa pembetulan dan penghilangan kesalahan berupa penyusunan bahan ajar yang tepat dan penentuan strategi pembelajaran yang serasi.

Secara teknis, alat yang digunakan dalam penelitian ini adalah komputer dengan perangkat lunak yang digunakan Microsoft Word 2017. Bahan yang diteliti ialah teks ulasan buku yang ditulis mahasiswa sebanyak 15 artikel resensi buku. Media yang digunakan untuk meneliti ialah review tools yang ada di Microsoft Word.

\section{HASIL DAN PEMBAHASAN}

Hasil penelitian terhadap bahasa tulis mahasiswa pada teks ulasan buku menunjukkan analisis kesalahan berbahasa ditemukan error sebanyak 424 item, mistake sebanyak 51 item, dan lapses 1 item. Artinya 89,08\% temuan kesalahan, 10,71\% temuan kekeliruan, dan $0,2 \%$ temuan ketidaksadaran. Sebaran kesalahan berbahasa tersebut dapat dilihat pada tabel berikut ini yang menunjukkan 15 artikel ulasan sebagai korpus data.

Tabel 1. Temuan hasil analisis kesalahan berbahasa

\begin{tabular}{cccc}
\hline Korpus Data & Lapses & Error & Mistake \\
\hline R-1 & 0 & 31 & 14 \\
R-2 & 0 & 42 & 11 \\
R-3 & 0 & 25 & 2 \\
R-4 & 0 & 22 & 1 \\
R-5 & 0 & 37 & 0 \\
R-6 & 0 & 14 & 1 \\
R-7 & 0 & 17 & 2 \\
R-8 & 0 & 19 & 0 \\
R-9 & 1 & 22 & 6 \\
R-10 & 0 & 18 & 0 \\
R-11 & 0 & 14 & 0 \\
R-12 & 0 & 18 & 1 \\
R-13 & 0 & 58 & 2 \\
R-14 & 0 & 38 & 6 \\
R-15 & 0 & 49 & 5 \\
\hline
\end{tabular}


Berdasarkan data tersebut dapat diketahui bahwa temuan error menyebar secara dominan di setiap artikel ulasan buku. Hal itu membuktikan bahwa tulisan mahasiswa mengalami kesalahan yang disebabkan oleh pelanggaran terhadap kaidah ejaan yang berlaku dalam bahasa Indonesia. Ejaan yang dijadikan standar analisis kesalahan berbahasa dalam penelitian ini adalah Ejaan Bahasa Indonesia (EBI) yang diresmikan melalui Permendikbud Nomor 50 Tahun 2015.

Dari data 424 item temuan error yang terdapat pada tabel 1, diketahui persentase analisis kesalahan berbahasa tulis berdasarkan EBI menunjukkan diagram berikut ini.

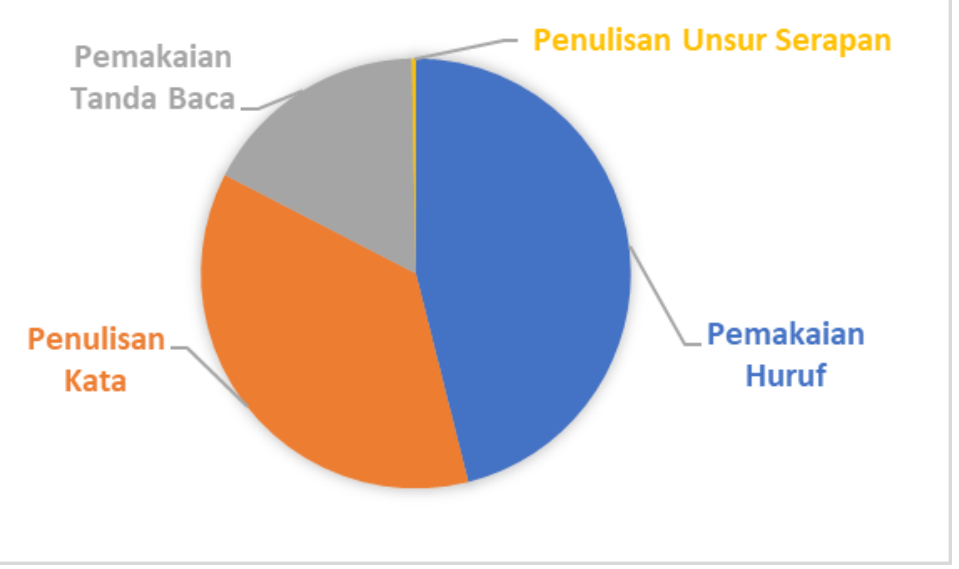

Gambar 1. Persentase kesalahan berbahasa berdasarkan Ejaan Bahasa Indonesia

Temuan error yang didasarkan pada kesalahan pemakaian huruf mencapai 183 item atau 43,16\%, temuan error yang didasarkan pada kesalahan penulisan kata mencapai 145 item atau $34,20 \%$, temuan error yang didasarkan pada pemakaian tanda baca mencapai 68 item atau 16,04\%, temuan error yang didasarkan pada penulisan unsur serapan mencapai 28 item atau 6,6\%. Sebaran kesalahan berbahasa dapat ditunjukkan pada tabel berikut ini.

Tabel 2. Analisis kesalahan berbahasa berdasarkan EBI

\begin{tabular}{|c|c|c|c|c|}
\hline Analisis & & Ejaa & ahasa Indonesia & \\
\hline $\begin{array}{l}\text { Korpus } \\
\text { Data }\end{array}$ & Pemakaian Huruf & Penulisan Kata & $\begin{array}{c}\text { Pemakaian Tanda } \\
\text { Baca }\end{array}$ & $\begin{array}{c}\text { Penulisan Unsur } \\
\text { Serapan }\end{array}$ \\
\hline R-1 & 7 & 14 & 4 & 6 \\
\hline R-2 & 18 & 15 & 7 & 2 \\
\hline R-3 & 11 & 10 & 3 & 1 \\
\hline
\end{tabular}




\begin{tabular}{|ccccc}
\hline R-4 & 6 & 6 & 7 & 2 \\
R-5 & 27 & 3 & 6 & 1 \\
R-6 & 6 & 5 & 2 & 1 \\
R-7 & 3 & 9 & 3 & 2 \\
R-8 & 7 & 9 & 1 & 2 \\
R-9 & 5 & 16 & 0 & 1 \\
R-10 & 10 & 6 & 1 & 1 \\
R-11 & 6 & 2 & 5 & 2 \\
R-12 & 7 & 3 & 6 & 3 \\
R-13 & 22 & 26 & 7 & 2 \\
R-14 & 16 & 11 & 9 & 1 \\
R-15 & 32 & 10 & 7 & 28 \\
\hline TOTAL & 183 & 145 & 68 & \\
\hline
\end{tabular}

Kesalahan dari aspek pemakaian huruf disebabkan disebabkan oleh beberapa hal berikut ini. Kesalahan yang dominan terjadi dikarenakan penggunaan kosakata dari bahasa asing yang tidak memakai huruf miring dan pemakaian huruf kapital yang seharusnya digunakan untuk menyebut nama orang, institusi, dan agama. Berikut ini temuan kesalahan selengkapnya dari kategori error pemakaian huruf.

\section{Tabel 3. Temuan Error Pemakaian Huruf}

\begin{tabular}{|c|c|c|c|}
\hline No & Penyebab Kesalahan Pemakaian Huruf & Letak Kesalahan & Perbaikan \\
\hline 1 & Pemakaian huruf kapital untuk singkatan & Sma, tbc & SMA, TBC \\
\hline 2 & $\begin{array}{l}\text { Pemakaian huruf kapital untuk nama } \\
\text { geografis }\end{array}$ & sunda, bali, hungaria & Sunda, Bali, Hungaria \\
\hline 3 & $\begin{array}{l}\text { Pemakaian huruf kapital untuk nama orang, } \\
\text { nama institusi, nama agama }\end{array}$ & $\begin{array}{l}\text { pratiwi, fakultas } \\
\text { dewi, ahmad }\end{array} \begin{array}{r}\text { salim } \\
\text { badawailan, islam, rahmad } \\
\text { widianto }\end{array}$ & $\begin{array}{l}\text { Pratiwi, Fakultas } \\
\text { Ekonomi, Dewi, Ahmad } \\
\text { Salim Badawailan, } \\
\text { Islam, Rahmad Widianto }\end{array}$ \\
\hline 4 & $\begin{array}{l}\text { Pemakaian huruf kapital pada kata ganti } \\
\text { nama orang/institusi/profesi di tengah } \\
\text { kalimat }\end{array}$ & $\begin{array}{l}\text { Saya, Sekolah Tinggi } \\
\text { swasta, Editor }\end{array}$ & $\begin{array}{l}\text { saya, sekolah tinggi } \\
\text { swasta, editor }\end{array}$ \\
\hline 5 & $\begin{array}{l}\text { Pemakaian huruf kapital pada kata ganti } \\
\text { yang menyatakan sapaan hormat }\end{array}$ & anda & Anda \\
\hline 6 & Pemakaian huruf kapital untuk judul & $\begin{array}{l}\text { "Yes aku bisa", } \\
\text { mengalahkan } \\
\text { kelemahan" }\end{array}$ & $\begin{array}{l}\text { "Yes Aku Bisa", "Kiat } \\
\text { Mengalahkan } \\
\text { Kelemahan" }\end{array}$ \\
\hline 7 & $\begin{array}{l}\text { Pemakaian huruf kapital untuk nama } \\
\text { peristiwa bersejarah }\end{array}$ & perang salib & Perang Salib \\
\hline 8 & $\begin{array}{l}\text { Pemakaian huruf miring untuk istilah dalam } \\
\text { bahasa asing }\end{array}$ & $\begin{array}{l}\text { man jadda wa jadda, thrust, } \\
\text { lift, drag, weight, safety, } \\
\text { cabin note, sweet heart, help } \\
\text { and hear, asses, respond, } \\
\text { take, citizen journalism, } \\
\text { quotes, science fiction, press } \\
\text { relation, public relations, } \\
\text { media relations, code of } \\
\text { conduct, design, romance, } \\
\text { catwalk, handbook, font, } \\
\text { deadline, chef, setting, }\end{array}$ & $\begin{array}{l}\text { man jadda wa jadda, } \\
\text { thrust, lift, drag, weight, } \\
\text { safety, cabin note, sweet } \\
\text { heart, help and hear, } \\
\text { asses, respond, take, } \\
\text { quotes, science fiction, } \\
\text { press relations, public } \\
\text { relations, code of } \\
\text { conduct, design, } \\
\text { romance, ratwalk, } \\
\text { handbook, font, deadline, }\end{array}$ \\
\hline
\end{tabular}




executive chef, book paper, chef, setting, executive
color full, actor, photoshop, chef, book paper, color
lay out, workspace, full, actor, photoshop,
retouching
lay out, workspace,
retouching

Berdasarkan hasil interaksi dalam proses pembelajaran, mahasiswa mengaku belum mengetahui tentang kaidah penulisan kata dari bahasa asing yang harus dicetak dengan huruf miring. Mengetahui hal tersebut, pada pembelajaran mahasiswa dilatih untuk menulis karangan ilmiah yang memuat delapan poin penyebab kesalahan berbahasa tulis tersebut.

Selanjutnya, kesalahan dari aspek penulisan kata disebabkan oleh tiga belas kesalahan. Kesalahan dominan yang terjadi pada tulisan mahasiswa pada ulasan buku terjadi pada penulisan imbuhan awal dan akhir yang tidak tepat, penulisan kata ulang, dan penulisan kata depan yang kurang tepat. Berikut ini temuan kesalahan selengkapnya dari kategori error penulisan kata.

Tabel 4. Temuan Error Penulisan Kata

\begin{tabular}{|c|c|c|c|}
\hline No & Penyebab Kesalahan Penulisan Kata & Letak Kesalahan & Perbaikan \\
\hline 1 & $\begin{array}{l}\text { Penulisan kata ganti nya/ku dipisah dengan } \\
\text { kata yang diikuti }\end{array}$ & $\begin{array}{l}\text { pertama nya, kenakalan nya, } \\
\text { menerjemahkan nya, } \\
\text { halaman nya, ku tepis, } \\
\text { dihalangi nya, kertas nya, } \\
\text { akhir nya, harga nya }\end{array}$ & $\begin{array}{l}\text { pertamanya, } \\
\text { kenakalannya, } \\
\text { halamannya, } \\
\text { menerjemahkannya, } \\
\text { kutepis, dihalanginya, } \\
\text { kertasnya, akhirnya, } \\
\text { harganya }\end{array}$ \\
\hline 2 & $\begin{array}{l}\text { Penulisan kata berimbuhan awal/akhir yang } \\
\text { tidak tepat }\end{array}$ & $\begin{array}{l}\text { di segani, di ceritakan, di } \\
\text { sarankan, di jelaskan, di } \\
\text { filmkan, di kekang, ke } \\
\text { galauan, di tolak, di teriama, } \\
\text { di terangkan, di pahami, di } \\
\text { selipkan, di pandang, di } \\
\text { baca, di siapkan, di tuliskan, } \\
\text { di rekomendasikan, di tulis, } \\
\text { di lakukannya, ter ulang, } \\
\text { mebuat, diprediksi kan, di } \\
\text { panggil, di jalaninya, di } \\
\text { perjelas, di bilang, di } \\
\text { gambarkan, di belokkan, di } \\
\text { hargai, di percaya, di } \\
\text { lencengkan, di-gunakan, } \\
\text { meng-gunakan, di lewati, } \\
\text { mem-praktikan }\end{array}$ & $\begin{array}{lr}\text { disegani, } & \text { diceritakan, } \\
\text { disarankan, } & \text { dijelaskan, } \\
\text { difilmkan, } & \text { dikekang, } \\
\text { kegalauan, } & \text { ditolak, } \\
\text { diterima, diterangkann, } & \text { diselipkan, } \\
\text { dipahami, } & \text { dibaca, } \\
\text { dipandang, } & \text { dituliskan, } \\
\text { disiapkan, } & \text { direkomendasikan, } \\
\text { ditulis, dilakukannya, } & \text { terulang, } \\
\text { diprediksikan, dipanggil, } \\
\text { dijalaninya, diperjelas, } \\
\text { dibilang, digambarkan, } \\
\text { dibelokkan, dihargai, } \\
\text { dipercaya, dilencengkan, } \\
\text { digunakan, } \\
\text { menggunakan, dilewati, } \\
\text { mempraktikkan }\end{array}$ \\
\hline 3 & Penulisan kata berimbuhan awal dan akhir & pahaman, & Kesalahpahaman, \\
\hline
\end{tabular}

AKSIS Jurnal Pendidikan Bahasa dan Sastra Indonesia

Volume 2 Nomor 2, Desember 2018 e-ISSN: 2580-9040

e-Journal: http://doi.org/10.21009/AKSIS 


\begin{tabular}{|c|c|c|c|}
\hline & yang kurang tepat & meceritakan & menceritakan \\
\hline 4 & Penulisan angka yang menyatakan urutan & ke tiga & ketiga \\
\hline 5 & $\begin{array}{l}\text { Penulisan angka yang terdiri atas satu/dua } \\
\text { kata tidak ditulis dalam bentuk kata }\end{array}$ & 4,3 & empat, tiga \\
\hline 6 & $\begin{array}{l}\text { Penulisan kata bentuk terikat yang kurang } \\
\text { tepat }\end{array}$ & non-fiksi, sub bab & nonfiksi, subbab \\
\hline 7 & $\begin{array}{l}\text { Penulisan kata berpartikel yang kurang } \\
\text { tepat }\end{array}$ & $\begin{array}{l}\text { sangat lah, aku lah, bukan } \\
\text { lah }\end{array}$ & $\begin{array}{l}\text { sangatlah, } \\
\text { bukanlah }\end{array}$ \\
\hline 8 & Penulisan kata hubung yang tidak tepat & $\begin{array}{l}\text { baik ... dan ..., namun, } \\
\text { Karena, } \\
\text { Sedangkan, Dan, bahkan }\end{array}$ & $\begin{array}{l}\text { baik .... maupun ..., } \\
\text { Namun, karena, sehingga, } \\
\text { sedangkan, dan, Bahkan, }\end{array}$ \\
\hline 9 & Penulisan kata ulang & $\begin{array}{l}\text { lupa lupa, pernak pernik, } \\
\text { nilai nilai, teori teori, bertele } \\
\text { tele, kemana mana, poin } \\
\text { poin, tips tips, berubah } \\
\text { ubah, cerita cerita, sumber } \\
\text { sumber, menutup nutupinya, } \\
\text { titik titik, kata kata, bagian } \\
\text { bagian, data data, berkali } \\
\text { kali, hal hal, ulasan ulasan, } \\
\text { resep resep, orang orang, } \\
\text { seolah olah, korban korban, } \\
\text { terngiang ngiang, data data, } \\
\text { lain lain }\end{array}$ & 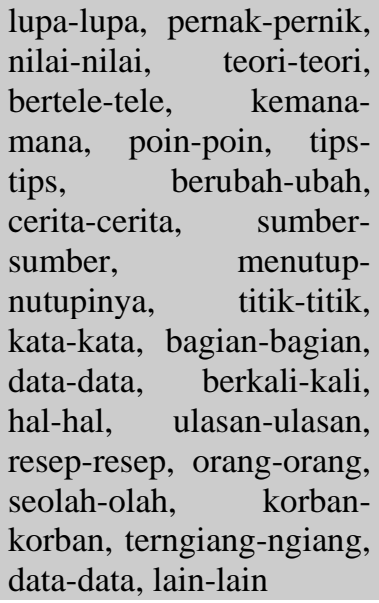 \\
\hline 10 & Penulisan unsur kata yang dicampur aduk & ditraining, beracting & dilatih, beraksi \\
\hline 11 & Penulisan kata yang tidak baku & $\begin{array}{l}\text { males, dan lain sebagainya, } \\
\text { karir, jaman, mendiagnosa }\end{array}$ & $\begin{array}{l}\text { malas, dan lain-lain, } \\
\text { karier, } \\
\text { zaman, } \\
\text { mendiagnosis }\end{array}$ \\
\hline 12 & Penulisan kata depan yang kurang tepat & $\begin{array}{l}\text { didalam, kedalam, disetiap, } \\
\text { disekolahnya, } \\
\text { dibidang, } \\
\text { dibelakangnya, } \\
\text { didalamnya, diakhir }\end{array}$ & $\begin{array}{l}\text { di dalam, ke dalam, di } \\
\text { setiap, di sekolahnya, ke } \\
\text { rumah, di bidang, ke } \\
\text { sana, di belakangnya, di } \\
\text { buku, di dalamnya, di } \\
\text { akhir }\end{array}$ \\
\hline 13 & Penulisan kata yang berlebihan (pleonatis) & $\begin{array}{l}\text { Banyak ulasan ulasan, } \\
\text { sangat banyak sekali }\end{array}$ & $\begin{array}{l}\text { Banyak ulasan, sangat } \\
\text { banyak }\end{array}$ \\
\hline
\end{tabular}

Data tersebut membuktikan bahwa mahasiswa belum sepenuhnya memahami penulisan kata

berimbuhan di- dengan penulisan kata depan di. Untuk mengatasi kesulitan tersebut, dijelaskan bahwa imbuhan di- diikuti oleh kata kerja yang menyatakan suatu tindakan tertentu dilakukan oleh subjek sedangkan kata depan di diikuti oleh unsur kalimat berupa keterangan tempat. Sebagai trik, dijelaskan bahwa kata kerja dapat diberi imbuhan di- jika kata kerja tersebut dapat dinyatakan dalam bentuk kata kerja aktif. Sebaliknya, kata depan yang merupakan keterangan tempat tidak bisa dinyatakan dalam bentuk kata kerja aktif meskipun diberi imbuhan awalan di-. 
Kajian bahasa ini menurut Chaer (2013) merupakan bagian kecil dari salah satu kajian struktur internal bahasa, yakni morfologi. Morfologi ialah kajian bahasa yang mengkaji proses pembentukan kata. Dalam konteks pembahasan ini, afiksasi atau pengimbuhan di- yang ditulis serangkai selalu diikuti oleh kata berjenis verba (di- + verba). Morfem ini menurut Yule (2015) disebut morfem infleksional karena tidak menghasilkan jenis kata baru tetapi hanya untuk mengindikasikan aspek fungsi gramatika kata.

Kesalahan berbahasa juga banyak terjadi karena pemakaian tanda baca yang kurang tepat. Dominasi kesalahan pemakaian tanda baca ialah pada penggunaan spasi yang mubazir di antara tanda strip (-). Temuan error ini terlihat pada data nomor 1 pada tabel 5. Selain itu, penggunaan tanda strip (-) untuk menyatakan sampai juga terjadi pada banyak kasus penggunaan, seperti terlihat di data nomor 4 pada tabel 5 berikut ini.

Tabel 5. Temuan Error Pemakaian Tanda Baca

\begin{tabular}{|c|c|c|c|}
\hline No & $\begin{array}{c}\text { Penyebab Kesalahan Pemakaian } \\
\text { Tanda Baca }\end{array}$ & Letak Kesalahan & Perbaikan \\
\hline 1 & $\begin{array}{l}\text { Penggunaan spasi yang tidak perlu secara } \\
\text { tanda baca (-) }\end{array}$ & $\begin{array}{l}\text { sehari - hari, teknik - } \\
\text { teknik, seolah - olah }\end{array}$ & $\begin{array}{l}\text { sehari-hari, teknik-teknik, } \\
\text { seolah-olah }\end{array}$ \\
\hline 2 & Pemakaian tanda baca (,) yang tidak perlu & $\begin{array}{llr}\text { Hafalan } & \text { Surat Delisa, dan } \\
\text { Moga } & \text { Bunda } \\
\text { Allah } & & \end{array}$ & $\begin{array}{l}\text { Hafalan Surat Delisa dan } \\
\text { Moga Bunda Disayang } \\
\text { Allah }\end{array}$ \\
\hline 3 & Penulisan gelar yang kurang tepat & M.Si & M.Si. \\
\hline 4 & $\begin{array}{l}\text { Penggunaan tanda baca sampai (-) yang } \\
\text { kurang tepat }\end{array}$ & bab $1-$ bab 6 & Bab $1-6$ \\
\hline 5 & $\begin{array}{l}\text { Penggunaan tanda baca (-) yang kurang } \\
\text { tepat }\end{array}$ & hitam - putih - abu abu & hitam, putih, abu-abu \\
\hline 6 & Penulisan simbol dan (\&) yang kurang tepat & tips\&trik & tips \& trik \\
\hline
\end{tabular}

Data tersebut membuktikan bahwa mahasiswa belum memahami sepenuhnya prinsip pemakaian tanda baca secara teknis, terutama penggunaan spasi yang mubazir. Untuk meluruskan ketidakpahaman tersebut, dijelaskan secara konseptual bahwa spasi digunakan setelah tanda baca digunakan secara sempurna sesuai fungsinya. 
Kesalahan penulisan unsur serapan didominasi oleh kesalahan penulisan kosakata bahasa Indonesia yang mengadaptasi dari kosakata bahasa Inggis dan bahasa Arab dengan varian kasus seperti yang teroihat pada tabel 6 berikut ini.

Tabel 6. Temuan Error Penulisan Unsur Serapan

\begin{tabular}{cllll}
\hline No & \multicolumn{1}{c}{$\begin{array}{c}\text { Penyebab Kesalahan Penulisan } \\
\text { Unsur Serapan }\end{array}$} & \multicolumn{1}{c}{ Letak Kesalahan } & Perbaikan \\
\hline $\mathbf{1}$ & $\begin{array}{l}\text { Penyerapan kosakata asing dari bahasa } \\
\text { Inggris berhuruf c menjadi k }\end{array}$ & cover & kover \\
$\mathbf{2}$ & $\begin{array}{l}\text { Penyerapan kosakata kata asing dari bahasa } \\
\text { Inggris bersuku kata -ple, -lar }\end{array}$ & simple, popular \\
$\mathbf{3}$ & $\begin{array}{l}\text { Penyerapan kosakata asing dari bahasa } \\
\text { Inggris bersuku kata akhir -nd }\end{array}$ & trend \\
$\mathbf{4}$ & $\begin{array}{l}\text { Penyerapan kosakata asing dari bahasa } \\
\text { Arab }\end{array}$ & sekedar, berfikir, nasehat \\
$\mathbf{5}$ & $\begin{array}{l}\text { Penyerapan kosakata asing dari bahas } \\
\text { Inggris bersuku kata akhir -ies }\end{array}$ & sekadar, berpikin \\
$\mathbf{6}$ & $\begin{array}{l}\text { Penyerapan kosakata asing dari bahasa } \\
\text { Inggris bersuku kata akhir -ign, -int }\end{array}$ & design, point \\
\hline
\end{tabular}

Berdasarkan data tersebut, dapat diketahui bahwa mahasiswa belum memiliki kepekaan dalam mengoreksi kosakata bahasa asing yang dapat diadaptasi ke dalam bahasa Indonesia. Untuk mengasah kepekaan tersebut, mahasiswa perlu dilatih secara lebih intensif dalam menganalisis kesalahan berbahasa. Mistake menunjukkan performansi mahasiswa sedangkan error menunjukkan kompetensi mahasiswa. Oleh karena itu, diperlukan serangkaian tahap mulai dari pendataan, penentuan error, penggambaran error, pengategorian error, dan penilaian error untuk membuat kesimpulan mengenai miskonsepsi mahasiswa tentang kesalahan bahasa tersebut.

Hasil analisis kesalahan berbahasa dan kesulitan mahasiswa dalam memahami kaidah kebahasaan ini akan menjadi bahan untuk memperbaiki perangkat pembelajaran bahasa. Hal itu seperti yang diungkapkan Richard (1985) bahwa tujuan error analysis ialah untuk mengidentifikasi strategi yang digunakan mahasiswa dalam mempelajari 
bahasa, mengidentifikasi penyebab kesalahan berbahasa, dan menyebutkan kesulitan umum dalam mempelajari bahasa sehingga dapat dijadikan bahan ajar untuk pengayaan pembelajaran menulis. Hal itu senada dengan penelitian yang dilakukan Ansoriyah (2018) bahwa kemampuan menulis mahasiswa dapat ditingkatkan dengan pendekatan whole language, yaitu pembelajaran yang dilakukan secara kontekstual dan alami, mahasiswa menulis sesuai dengan apa yang diketahui dan dosen memberikan stimulus, kemudian mahasiswa yang mengembangkan secara utuh dalam lingkungan belajar yang nyaman.

\section{KESIMPULAN}

Berdasarkan hasil analisis dapat disimpulkan bahwa kesalahan berbahasa kategori error mencapai 89,08\%. Dari 424 temuan kesalahan, kesalahan pemakaian huruf mencapai 183 item atau 43,16\% dengan dominasi kesalahan pada pemakaian huruf miring, kesalahan penulisan kata mencapai 145 item atau 34,20\% dengan dominasi kesalahan pada penulisan kata berimbuhan awal di- dan kata depan di, kesalahan pemakaian tanda baca mencapai 68 item atau 16,04\% dengan dominasi kesalahan pada penggunaan spasi yang mubazir, dan kesalahan penulisan unsur serapan mencapai 28 item atau 6,6\% dengan dominasi kesalahan pada penulisan kosakata bahasa Indonesia yang diadaptasi dari bahasa Inggris dan Arab.

AKSIS Jurnal Pendidikan Bahasa dan Sastra Indonesia 


\section{UCAPAN TERIMA KASIH}

Ucapan terima kasih disampaikan kepada Kementerian Riset Teknologi dan Pendidikan

Tinggi yang telah mendanai penelitian ini melalui skema penelitian kompetitif nasional Penelitian Dosen Pemula (PDP).

\section{DAFTAR PUSTAKA}

Ansoriyah, S. \& Aceng R. (2018). Peningkatan Kemampuan Menulis Populer Mahasiswa Melalui Pendekatan Whole Language dengan Pembuatan Media Story Board. Aksis: Jurnal Pendidikan Bahasa dan Sastra Indonesia, 2 (1). 29-46 doi.org/10.21009/AKSIS.02.0103

Brown, H. D. (2000). Principles of Language Learning and Teaching Fourth Edition. New York: Addison Wesley Longman.

Chaer, A. (2013). Kajian Bahasa (Struktur Internal, Pemakaian, dan Pemelajaran). Jakarta: Penerbit Rineka Cipta.

Dulay, H.C., Burt, M.K., Krashen, S. (1982). Language Two. New York: Oxford University Press.

Ellis, R. (2008). The Study of Second Language Acquisition. Oxford: Oxford University Press.

Fisiak, J. (1981). Constrative Linguistics and the Langauge Teacher. Oxford: Pergamon Press.

Gantamitreka \& Shokha. (2016). Kesalahan Berbahasa. Solo: Genta Smart Publisher

Kosasih, E. (2017). Jenis-Jenis Teks (Analisis Fungsi, Struktur, dan Kaidah serta Langkah Penulisannya). Bandung: Penerbit Yrama Widya.

Kurniadi, F. (2017). Penulisan Karya Tulis Ilmiah Mahasiswa dengan Media Aplikasi Pengolah Kata. Aksis: Jurnal Pendidikan Bahasa dan Sastra Indonesia, 1(2). 189-203. DOI: doi.org/10.21009/AKSIS.010208

AKSIS Jurnal Pendidikan Bahasa dan Sastra Indonesia

Volume 2 Nomor 2, Desember 2018 e-ISSN: 2580-9040

e-Journal: http://doi.org/10.21009/AKSIS 
Norish, J. (1983). Language Learners and theirs Errors. London: Macmillan Press.

Richard, J.C., et al. (1985). Longman Dictionary of Language Teaching and Applied Linguistics. London: Longman.

Utami, S. R. (2017). Pembelajaran Aspek Tata Bahasa dalam Buku Pelajaran Bahasa Indonesia. Aksis: Jurnal Pendidikan Bahasa dan Sastra Indonesia, 1(2). 189203. doi: doi.org/10.21009/AKSIS.010203

Suriasumantri, J. S. (2005). Filsafat Ilmu Sebuah Pengantar Populer. Jakarta: Pustaka Sinar Harapan.

Tarigan, H. G. (1990). Pengajaran Analisis Kesalahan Berbahasa. Bandung: Penerbit Angkasa.

Tim Perumus Pusat Pengembangan Literasi dan Profesi Komunikasi. (2018). Standar Kompetensi Kerja Nasional Indonesia Kategori Informasi dan Komunikasi Golongan Pokok Aktivitas Penerbitan Bidang Penerbitan Buku. Jakarta: Kementerian Ketenagakerjaan Republik Indonesia.

Yule, G. (2015). The Study of Language. Yogyakarta: Pustaka Pelajar. 